\title{
Relevansi Teori Belajar Behaviorisme Terhadap Pendidikan Agama Islam
}

\author{
Yoga Anjas Pratama* \\ Universitas Islam Negeri Sunan Kalijaga Yogyakarta, Indonesia \\ Jl. Marsda Adisucipto, Yogyakarta 55281, Indonesia \\ Email: yogaanjasp8@gmail.com
}

\begin{abstract}
The behaviorism learning theory can be used to help the learning process. But it is known that many experiments in behaviorist theory are carried out using animals thus raising questions, whether the behaviorism learning theory is in line with Islamic teachings and can be used in Islamic Education. This research is a library research that is analyzed using content analysis techniques. The results of this study are, found it the relevance of behaviorism learning theory to Islamic education, as follows: (1) Behaviorism learning theory can be used to help the learning process of Islamic education (2) The behaviorism learning theory is a learning theory that is in line with the teachings of Islam (3) The existence of conditioning (classical conditioning), repetition and reinforcement in behaviorism theory which is also used in learning Islamic education (4) The theory of behaviorism according to edward lee throndike contains four laws, namely: law of readiness, law of exercise, law of effect, dan law of attitude, which is in line with the learning process of Islamic education.
\end{abstract}

Keywords: Relevance, Behaviorism Theory of Learning, Islamic Education

Abstrak: Teori belajar behaviorisme dapat digunakan untuk membantu proses pembelajaran. Namun diketahui bahwa banyak percobaan dalam teori behaviorisme dilakukan dengan menggunnakan hewansehingga menimbulkan pertanyaan, apakah teori belajar behaviorisme sejalan dengan ajaran agama Islam dan dapat digunakan dalam Pendidikan Islam. Penelitian ini merupakan penelitian kepustakaan yang dianalisis dengan menggunakan teknik analisis konten. Hasil dari penelitian ini adalah ditemukan adanya relevansi antara teori belajar behaviorisme terhadap pendidikan Islam, sebagai berikut: (1) Teori belajar behaviorsime dapat digunakan untuk membantu proses pembelajaran pendidikan Islam (2) Teori belajar behaviorsime merupakan teori belajar yang sejalan/berkaitan dengan ajaran agama Islam (3) Adanya pengkondisian (clasical conditioning), pengulangan dan penguatan dalam teori behaviorsime yang juga digunakan dalam pembelajaran pendidikan Islam (4) Teori belajar behaviorsime menurut Edward Lee Thorndike mengandung empat hukum, yaitu: law of radiness (hukum kesiapan), law of exercise (hukum latihan), law of effect (hukum latihan), dan law of attitude (hukum sikap), yang sejalan/berkaitan dengan proses pembelajaran pedidikan Islam.

Kata Kunci: Relevansi, Teori Belajar Behaviorisme, Pendidikan Islam

Jurnal Pendidikan Agama Islam Al-Thariqah Vol. 4, No. 1, Januari - Juni 2019

Received: 14 February 2019; Accepted 19 March 2019; Published 1 June 2019

*Corresponding Author: yogaanjasp8@gmail.com 


\section{PENDAHULUAN}

Belajarmerupakan suatu proses dimana suatu organisasi berbuah perilakunya sebagai akibat pengalaman (Dahar, 2011: 2). Bagi sebagian orang belajar dianggap berhasil apabila seseorang telah dapat membaca, menulis, menghafalkan materi pembelajaran, menjawab pertanyaan, dan lain sebagainya. Namun hakikat belajar bukanlah sebatas demikian. Seseorang dapat dikatakan belajar apabila telah terjadi perubahan pada diri seseorang tersebut, baik itu berupa kognitif, afektif, maupun psikomotorik.

Saat ini di dalam dunia pendidikan banyak sekali dikembangkan dan digunakan teori-teori belajar. Teori belajar digunakan untuk membantu pendidik dan peserta didik dalam mendesain pembelajaran sehingga dapat memberikan kemudahan kepada pendidik dan peserta didik dalam mencapai tujuan pembelajaran yang telah ditetapkan. Teori belajar itu sendiri merupakan gabungan prinsip yang saling berhubungan dan penjelasan atas sejumlah fakta serta penemuan yang berkaitan dengan peristiwa belajar (Nahar, 2016: 64).

Teori belajar terbagi menjadi tiga, yaitu: (1) Teori behaviorisme (behavioristik) (2) Teori kognitif, dan (3) Teori humanisme. Teori behaviorisme lebih menekankan pada pembentukan tingkah laku berdasarkan stimulus dan respon yang bisa diamati. Teori ini berlawanan dengan teori kognitif yang lebih menekankan pada proses belajar atau mental yang bisa diamati secara kasat mata. Sedangkan teori humanistik merupakan teori penengah dari kedua teori tersebut, yakni teori yang memandang manusia sebagai mahluk yang berharga (Rusuli, 2014: 39).

Teori behaviorisme dalam pembelajaran dapat digunakan untuk melatih refleks-refleks sedemikian rupa sehingga menjadi suatu kebiasaan yang dikuasai individu (Suyono \& Hariyanto,
2011: 59). Artinya suatu pembelajaran harus dapat melatih individu peserta didik dengan menggunakan stimulus dan respon sehingga hasil dari belajar tersebut merupakan sesuatu yang dapat dikuasai oleh peserta didik.

Menurut Edward Lee Thorndiketeori belajar behaviorisme merupakan proses interaksi antara stimulus dan respon. Kemudian menurut John Broadus Watson stimulus tersebut harus berbentuk tingkah laku yang dapat diamati (observable) (Ratnawati: 11-12). Dengan demikian maka suatu pembelajaran harus dapat menciptakan stimulus dan respon yang dapat diamati dan dapat membantu peserta didik dalam menguasasi suatu pelajaran. Untuk itu dalam suatu pembelajaran dibutuhkanya trial and eror, clasical conditiong, dan stimulus respon.

Teori belajar behaviorsime pada dasarnya digunakan untuk membantu suatu pembelajaran sehingga dari pembelajaran tersebut dapat membentuk perilaku peserta didik yang baik dan diinginkan. Namun sebelum menggunakan teori behaviorisme dalam pembelajaran hendaklah diketahui secara lebih medalam mengenai teori belajar behaviorismeagar apa yang diinginkan dari sebuah pembelajaran dapat tercapai. Selain itu percobaan-percobaan dalam teori behaviorsime banyak dilakukan dengan menggunakan hewan seperti: anjing, kucing, dan lain lain. Hal ini menimbulkan pertanyaan, apakah teori belajar behaviorisme sejalan dengan ajaran agama Islam, dan dapat digunakan dalam Pendidikan Islam. Persoalan ini penting untuk diketahui sebab dalam dunia pendidikan Islam khususnya Indonesia sangat akrab dengan teori ini.

Berangkat dari permasalahan di atas maka dalam penelitian ini akan mencoba mengkaji lebih mendalam mengenai relevansi teori belajar behaviorisme tehadap pendidikan Islam yang ditinjau dari behaviorisme Edward Lee Thorndike dan John Broadus Watson. 


\section{METODE PENELITIAN}

Penelitian ini merupakan penelitian kepustakaan (library research), yaitu penelitian yang dilakukan dengan menggunakan buku-buku, artikel, dan dokumen-dokumen lainya sebagai sumber data dalam penelitian. Penelitian ini difokuskan pada kajian mengenai relevansi teori belajar behaviorsime terhadap pendidikan Islam yang ditinjau dari behaviorisme Edward Lee Throndike dan John Broadus Watson. Dalam penelitian ini penulis mengumpulkan data dengan cara penelurusan, yaitu suatu cara dimana penulis melakukan penelusuran terhadap sumber data (buku, artikel, majalah, dan dokumen-dokumen lainya yang terkait), untuk kemudian dilakukan analisis data dengan menggunakan analisis konten (content analysis). Analisis konten merupakan suatu tekhnik yang digunakan untuk menarik kesimpulan akhir melalui karakteristik pesan yang dilakukan secara objektif dan sistematis (Moelong, 2015: 26). Dengan kata lain data-data yang telah diperoleh (dari sumber kepustakaan) dianalisis untuk kemudian ditemukan sebuah kesimpulan akhir yang valid dan relevan dengan penelitian yang dilakukan.

\section{KONSEP UTAMA TEORI BELAJAR BEHAVIORISME}

$\begin{array}{crr}\text { Teori } & \text { belajar } & \text { behaviorsime } \\ \text { memandang } & \text { bahwa } & \text { belajar }\end{array}$
merupakanproses perubahan tingkah laku sebagai akibat dari interaksi antara stimulus dan respons (Sanjaya, 2008: 238). Belajar menurut psikologi behavioristik merupakan suatu kontrol instrumental yang berasal dari lingkungan. Dengan demikian maka belajar tidaknya seseorang bergantung pada faktor-faktor kondisional yang diberikan lingkungan (Siregar \& Hartini, 2011: 25).

Teori belajar behaviorsime memiliki beberapa ciri, sebagai berikut: (1) Mengutamakan unsur-unsur atau bagian- bagian kecil (2) Bersifat mekanis (3) Menekankan peranan lingkungan (4) Mementingkan pembentukan respon (5) Mementingkan pentingnya latihan (Suyono \& Hariyanto, 2011: 58).

Belajar dalam behaviorsme dapat dilakukan dengan melatih refleks-refleks sedemikian rupa sehingga dapat menjadi suatu kebiasaan yang dikuasai individu. Menurut behaviorisme belajar merupakan suatu akibat dari adanya interaksi antara stimulus (S) dengan respon (R). Menurut teori ini, dalam belajar yang penting adalah adanya input berupa stimulus dan output yang berupa respon (Andriyani, 2015: 96).

Belajar dalam behaviorsime memiliki kosep dasar, yaitu bahwa belajar merupakan proses interaksi antara stimulus atau rangsangan yang berupa serangkaian kegiatan yang bertujuan agar mendapatkan respon belajar dari objek penelitian. Respon itu sendiri adalah reaksi yang dimunculkan peserta didik ketika belajar yang dapat berupa pikiran, perasaan, atau pun tindakan (Suyono \& Hariyanto, 2011: 59). Dikutip Suyono \& Hariyanto (2011: 60) dari Di Vesta dan Thopson, bahwa konsep belajar behaviorisme, ialah sebagai berikut:
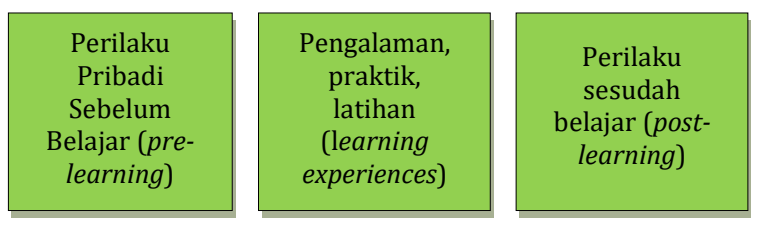

Gambar 1: Konsep Dasar Perilaku Belajar Menurut Behaviorsime.

\section{Teori Belajar Behavirosisme Edward Lee Thorndike}

Edward Lee Thorndike merupakan seorang psikologi Amerika yang lahir pada 31 Agustus 1874 (Rahyubi, 2014: 31). Menurut Thorndike belajar merupakan proses interaksi antara stimulus yang mungkin berupa pikiran, perasaan, atau gerakan dan respon yang juga mungkin berupa pikiran, perasaan, atau gerakan (Andriyani, 2015: 170). 
Proses belajar menurut Thorndike memiliki bentuk yang paling dasar, yaitu: trial and eror learning (belajar uji coba), atau disebut juga sebagai selecting and connecting (pemilihan dan pengaitan) (Hergenhahn \& Olson, 2008: 60).

Edward Lee Thorndike pada awalnya melakukan percobaan terhadap seekor kucing dan di masukan kedalam sebuah kotak yang didalamnya terdapat banyak labirin (Andriyani, 2015: 170), yang dilengkapi sebuah tombol pembuka yang dapat ditekan. Kemudian pada bagian luar kerangkeng diletakkan daging. Kucing yang ada dalam kerangkeng kemudian bergerak kesana ke mari mencari jalan keluar, tetapi gagal. Kucing tersebut terus melakukan usaha dan gagal, keadaan ini berlangsung terus menerus. Tak lama kemudian kucing tanpa sengaja menekan tombol sehingga tanpa sengaja pintu kotak kerangkeng terbuka dan kucing dapat memakan daging didepanya (Irwan, 2015: 100). Percobaan tersebut dilakukan berulang-ulang.

Pada awalnya gerakan kucing sangat lama/lambat dalam membuka pintu (menekan tombol pembuka), namun setelah dilakukan percobaan secara berulang-ulang akhirnya kucing tersebut mengalami sebuah kemajuan tinggkah laku, dan pada akhirnya ketika kucingtersebut dimasukkan kembali kedalam box, kucing tersebut dapat menemukan dan menekan tombol pembuka pintu dengan sekali usaha hingga pintu terbuka (Irwan, 2015: 100).

Dari percobaan yang dilakukan, Thorndike menyatakan bahwa perilaku belajar manusia ditentukan oleh stimulus yang ada di lingkungan sehingga dapat menimbulkan respon secara refleks (Irwan, 2015: 101). Thorndike menyimpulkan bahwa respons untuk keluar kandang secara bertahap diasosiasikan sebagai stimulus dalam suatu proses coba-coba (trial and error). Kemudian respons yang benar secara bertahap diperkuat melalui serangkaian proses coba-coba, sementara respons yang tidak benar akan melemah dan menghilang (Winataputra dkk, 2011: 2.9). Dengan demikian maka jelaslah bahwa konsep belajar menurut Thorndiketerdiri dari stimulus dan respon yang nantinya akan menghasilkan perubahan tingkah laku pada peserta didik.

Edward Lee Thorndike dalam hal ini mengembagkan teori connectionisme atau trial and eroryang didasarkan atas percobaannya terhadap kucing. Belajar menurut teori ini ditunjukkan dengan adanya proses trial and eror (Rusuli, 2014: 42). Dari trial and eror, Throndike kemudian mengemukakan beberapa hukum yang berkaitan dengan proses belajar, sebagai berikut:

Pertama, hukum kesiapan (law of readiness). Dikutip dari B.R. Hergenhahn \&Mattew H. Olson (2008: 64) bahwa Law of readiness atau hukum kesiapan mengandung tiga bagian, sebagai berikut: (1) Apabila satu unit konduksi siap menyalurkan (to conduct), maka penyaluran denganya akan memuaskan(2) Apabila satu unit konduksi belum siap untuk menyalurkan, maka tidak menyalurkanya akan menjengkelkan (3) Apabila satu unit konduksi belum siap untuk penyaluran dan dipaksa untuk menyalurkan, maka penyaluran denganya akan menjengkelkan.

Kedua, hukum latihan (law of exercise).Law of ecercise mengatakan bahwa semakin sering tingkah laku diulang, dilatih, dan dipraktikkan, maka asosiasi tersebut akan semakin kuat. Prinsip law of exeecise adalah bahwa koneksi antara kondisi yang merupakan perangsang dengan tindakan akan menjadi lebih kuat karena latihan-latihan, tetapi akan menjadi lemah bila koneksi antar keduanya tidak dilanjutkan atau dihentikan. Prinsip utama dalam belajar menurut law of exercise adalah pengulangan, bahwa apabila makin sering diulang, materi pelajaran akan semakin dikuasai (Rahyubi, 2014: 36). 
Ketiga, hukum akibat (law of effect). Law of effect merupakan hubungan stimulus respons yang cenderung diperkuat bila akibatnya menyenangkan, dan sebaliknya cenderung diperlemah jika akibatnya tidak memuaskan. Menurut law of effect jika suatu respons menghasilkan situasi yang memuaskan, maka koneksi S$\mathrm{R}$ akan menguat (Hergenhahn \& Olson, 2008: 66). Hukum ini menunjuk pada makin kuat atau makin lemahnya koneksi sebagai hasil perbuatan. Suatu perbuatan yang disertai akibat menyenangkan cenderung dipertahankan dan lain kali akan diulangi lagi. Sebaliknya jika perbuatan yang mengakibatkan hal yang tidak menyenangkan cenderung dihentikan dan tidak diulangi lagi (Rahyubi, 2014: 36-37).

Keempat, hukum sikap (law of attitude). Menurut law of attitude bahwa perilaku belajar seseorang tidak hanya ditentukan oleh hubungan stimulus dan respons saja, tetapi juga ditentukan oleh keadaan yang ada dalam diri individu, baik menyangkut aspek kognitif, emosi, sosial, maupun psikomotornya (Rahyubi, 2014). Dengan demikian maka respons terhadap situasi eksternal tergantung pada kondisi individu serta hakikat dari situasi tersebut. Sesuatu yang dianggap menarik dan memuaskan oleh seorang individu tetapi tidak bisa dipungkiri sangat mungkin dianggap sebaliknya oleh individu lainya. Sama-sama menghadapi materi, persoalan dan obyek yang sama, seorang individu bisa saja memunculkan kesan dan reaksi yang beragam dan berbeda (Rahyubi, 2014: 36-37).

Teori connectisme merupakan teori yang menyatakan bahwa adanya hubungan antara stimulus dan respons yang diberikan oleh organisme terhadap stimulus awal (Rusuli,2014: 42). Dengan begitu maka teori ini mengasumsikan bahwa tingkah laku peserta didik pada hakikatnya ialah merupakan suatu respons terhadap lingkungan yang lalu dan sekarang dan semua tingkah laku yang dipelajari (Djiwandono, 1989: 51).

Dari asumsi tersebut maka seorang guru yang memiliki fungsi pendidik pada lingkungan sekolah sebaiknya mampu untuk menciptakan lingkungan belajar yang memungkinkan terjadinya penguatan (reinforcement) pada diri peserta didik. Lingkungan belajar yang dimaksud ialah berupa benda, sarana prasarana, orang atau pun situasi tertentu yang semuanya dapat memunculkan dan berdampak pada tingkah laku peserta didik. Berikut gambar ilustrasi reinforcement dalam pembelajaran yang dikutip dari Muh Hizbul Arifin dalam Aplikasi dan Implikasi Teori Behaviorisme dalam Pembelajaran: Analisis Strategis Inovasi Pembelajaran (4):

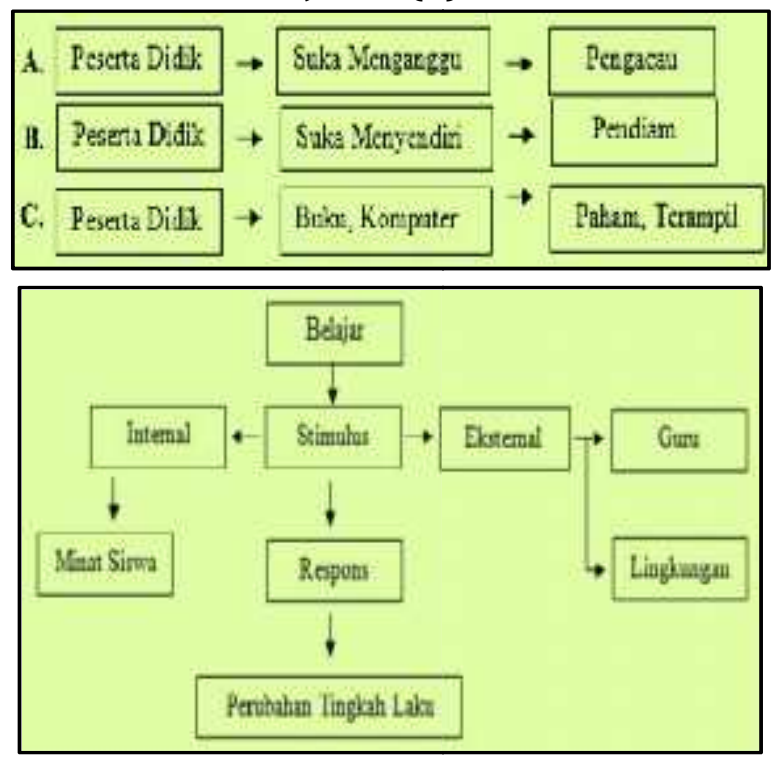

Gambar 2: Ilustrasi Reinforcement Bagi Peserta Didik.

Dari gambar diatas dapat dipahami bahwa pada gambar A, peserta didik yang memiliki perangai suka menganggu terhadap temanya pada setiap waktu dan temanya tersebut bersikap kooperatif dan mau menanggapi semua obrolanya, maka lingkunganya akan bersifat kondusif atau dapat memberikan penguatan (reinforcement) sehingga hal tersebut akan membentuk peserta didik menjadi peserta didik yang berperilaku sebagai pengecau. Sebaliknya pada gambar B, karena lingkunganya tidak memberikan 
penguatan (reinforcement) terhadap sikap dan tingkah laku peserta didik maka lingkungan tersebut akan membentuk peserta didik menjadi peserta didik yang pendiam. Sedangkan pada gambar C, peserta didik yang berada pada lingkungan yang mempunyai ketersediaan sumber belajar yang memadai seperti: buku, majalah, komputer dan lain-lain, akan dapat memberikan penguatan dan membentuk peserta didik menjadi peserta didik yang paham, mengerti, dan terampil dalam memahami dan menggunakan sumber belajar (Muflihin: 4).

\section{Teori Belajar Behaviorsime John Broadus Watson}

John Broadus Watson lahir pada 9 Januari 1958 di South Carolina USA, dan meninggal di New York pada 25 September 1958 (Andriyani, 2015: 171). Belajar menurut Watson merupakan sebuah proses interaksi antara stimulus dan respons, namun stimulus dan respons yang dimaksud harus berbentuk tingkah laku yang dapat diamati (observabel) dan dapat diukur(Irwan, 2015: 104). Dengan kata lain Watson mengakui adanya perubahan-perubahan mental dalam diri seseorang selama proses belajar, namun ia menganggap hal tersebut sebagai faktor yang tak perlu diperhitungkan, karena hal tersebut tidak dapat menjelaskan apakah seseorang telah belajar atau belum, dan karena hal tersebut tidak dapat diamati (Irwan, 2015: 104).

John Boardus Watson pernah melakukan percobaan yang pernah diterapkan pavlov mengenai classical conditioning, yaitu dengan menggunakan seekor tikus dan seseorang anak yang bernama Albert. Dari percobaan tersebut Watson percaya bahwa manusia dilahirkan dengan beberapa refleks dan reaksi emosional seperti cinta, kebencian, dan kemarahan (Andriyani, 2015: 171).

Teori belajar yang dikembangan Watson adalah Sarbon (stimulus and response bond theoriy). Teori ini secara umum adalah sama dengan teori Thorndike yaitu Connectionisme dan teori Pavlov Clasical Conditioning, hal ini dikarenakan yang menjadi landasan dari teori behaviorisme Watson adalah teori Thorndike dan Pavlov. Watson menggunakan teori Clasical Conditioning Pavlov dalam hal interaksi antara stimulus dan respons yang dilengkapi dengan komponen penguatan (reinforcement) dari Thorndike (Winataputra dkk, 2011: 2.10-2.11).

Sarbon (stimulus and response bond theoriy) adalah teori yang memandang bahwa belajar merupakan proses terjadinya refleks-refleks atau responsrespons bersyarat melalui stimulus (Rusuli, 2014: 42). Menurut Watson manusia dilahirkan dengan beberapa refleks dan reaksi-reaksi emosional seperti takut, cinta, dan marah. Semua tingkah laku tersebut terbentuk oleh adanya hubungan antara stimulus dan respons baru melalui conditioning, sehingga belajar dapat dipandang sebagai cara menanamkan sejumlah ikatan antara perangsang dan reaksi dalam sistem susunan syaraf (Rusuli, 2014: 42). Berikut gambar proses belajar dan pembelajaran menurut John Broadus Watson (Rahyubi, 2014: 19) :

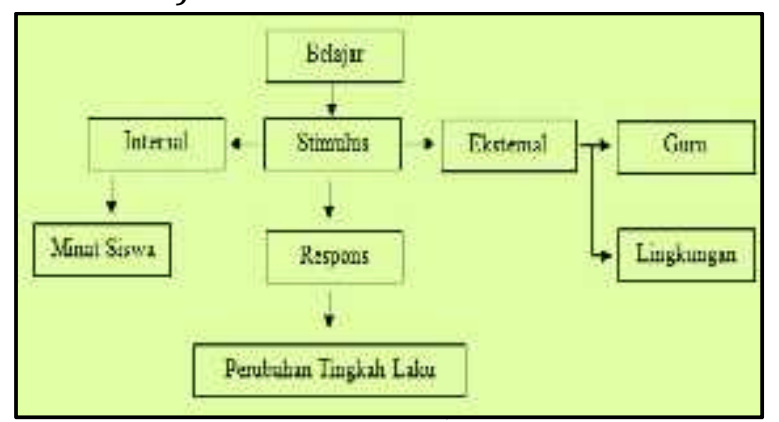

Gambar 3: Skema Proses Belajar dan Pembelajaran Menurut John B. Watson.

Dari gambar di atas dapat dipahami bahwa dalam proses belajar dan pembelajaran hal yang paling penting adalah input yang berupa stimulus dan output yang berupa respons. Stimulus adalah apa saja yang diberikan guru kepada peserta didik, sedangkan respons 
ialah reaksi atau tanggapan peserta didik terhadap stimulus yang diberikan oleh seorang guru (Rahyubi, 2014: 19). Dalam teori Sarbon guru dituntut untuk dapat merancang atau mengkondisikan lingkungan belajar, baik itu berupa kelas, saraprasarana, maupun kondisi belajar peserta didik, sehingga hal tersebut dapat mempengaruhi respons yang diberikan peserta didik. Dengan demikian maka jika guru menginginkan seorang murid yang aktif, baik, paham dan terampil, maka hal yang perlu dilakukan adalah merancang dan memberikan lingkungan belajar yang baik.

\section{Relevansi Teori Belajar Behaviorisme Edward Lee Thorndike dan John Broadus Watson Terhadap Pendidikan Islam}

Pendidikan Islam merupakan pendidikan yang didasarkan pada nilainilai ajaran Islam sebagaimana tercantum dalam alquran dan hadis serta dalam pemikiran para ulama dan dalam praktik sejarah umat Islam (Nata, 2008: 173). Dikutip dari M. Sudiyono (2009: 180) bahwa pendidikan Islam merupakan bimbingan secara tidak sadar dari pendidik (orang dewasa) kepada anak yang masih dalam proses pertumbuhanya, berdasarkan norma-norma Islami, agar terbentuk keperibadiannya menjadi kepribadian musllim.

Pendidikan Islam secara umum memiliki tujuan, sebagai berikut: (1) Mewujudkan manusia yang berkepribadian Islam (2) Melatih dan membimbing agar peserta didik menguasai tsaqafah (3) Melatih dan membimbing peserta didik agar dapat menguasai ilmu kehidupan (IPTEK) (4) Melatih dan membimbing peserta didik agar memilliki keterampilan yang memadai (Munchith, 2009: 35-46). Dalam prosesnya, pendidikan Islam menjadikan tujuan sebagai sasaran ideal yang hendak dicapai dalam program dan diproses dalam produk kependidikan Islam atau output kependidikan Islam (Arifin, 2009: 162).

Dari penjelasan diatas maka dapat dipahami bahwa pendidikan Islam merupakan pendidikan yang didasarkan atas alquran, hadis, dan norma-norma Islam yang diberikan oleh orang dewasa (guru) kepada anak (peserta didik) agar dapat terbentuknya kepribadian muslim pada diri anak tersebut.

Pendidikan Islam pada umumnya diberikan oleh guru dalam bentuk proses belajar mengajar. Belajar pada dasarnya adalah tahapan perubahan perilaku siswa yang relatif positif dan menetap sebagai hasil interaksi dengan lingkungan yang melibatkan proses kognitif. Proses kognitif tersebut meliputi persepsi atau pengamatan, tanggapan atau bayangan, asosiasi dan reproduksi, fantasi, memori atau ingatan dan kecerdasan (Zulhammi, 2015: 110).

Belajar dalam perspektif Islam merupakan kewajiban bagi setiap muslim dalam rangka meningkatkan derajat, menambah ilmu pengetahuan, serta menambah keimanan. Hasil dari belajar diharapkan dapat membentuk insan kamil yang beriman, berahlak, dan berilmu yang terwujud dalam bentuk tingkah laku dan aktivitas sehari-hari. Berikut fiman Allah dalam Q.S. Al-Mujadalah ayat 11:

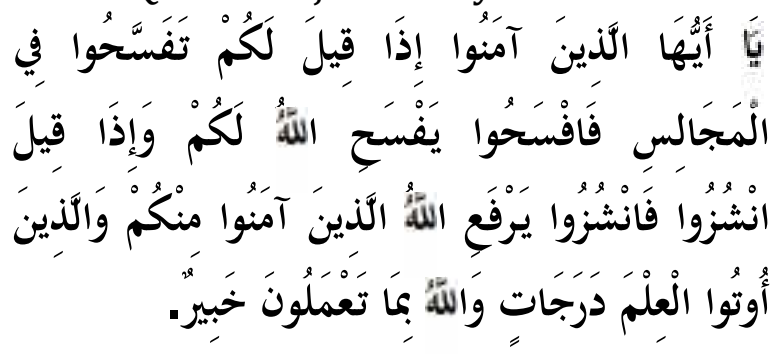

"Hai orang-orang yang beriman apabila dikatakan kepadamu "Berlapang-lapanlah dalam suatu majelis" maka lapakanlah niscahaya Allah akan memberikan kelapangan untukmu. Dan apabila dikatakan "Berdirilah kamu" maka berdirilah, niscayaAllah akan meninggikan orang-orang yang beriman diataramu dan orang-orang yang diberi pengetahuan berapa derajat. Dan Allah Maha 
Mengetahui apa yang kamu kerjakan" (Kementerian Agama Republik Indonesia, 2014: 543).

Belajar dalam kaitanya dengan teori behaviorsime dipandang sebagai proses perubahan tingkah laku sebagai akibat dari adanya interaksi antara stimulus dan respons (Yuningsih, 2011: 7). Stimulus tersebut dapat berupa lingkungan peserta didik dan dapat juga berbentuk tingkah laku yang dapat diamati (observabel) (Ratnawati: 11-12). Dalam Islam teori belajar behaviorisme kaitanya dengan unsur lingkungan (lingkungan belajar) bukanlah sesuatu yang baru, hal ini dijelaskan dalam hadis Nabi Muhammad SAW sebagai berikut:

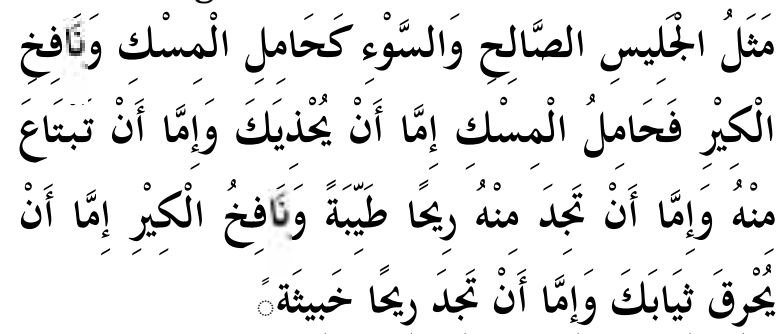

"Perumpamaan teman yang baik dan teman yang buruk seperti pedagag minyak kesturi dan peniup apa tukang besi. Si pedangang minyak kesturi mungkin akan memberiknya kepadamu atau engkau membeli kepadanya atau setidaknya engkau dapat memperoleh baru yang harum darinya, tapi si peniup api tukang besi mungkin akan membuat badamu atau pakaianmu terbakar atau mungkin engkau mendapat bau yang tidak sedap darinya". (H.R. Bukhari dan Muslim) (Andriyani, 2015: 175).

Dari hadis di atas dapat dipahami bahwa lingkungan sangat berpengaruh terhadap seseorang. Dalam belajar seorang peserta didik dipengaruhi dan dibentuk oleh lingkungan sekitarnya. Dengan demikian maka lingkungan belajar yang baik akan membentuk perilaku yang baik begitu pun sebaliknya lingkungan belajar yang buruk akan membentuk perilaku yang buruk. Hal ini dijelaskan dalam Q.S. Thaha ayat 132, sebagai berikut:

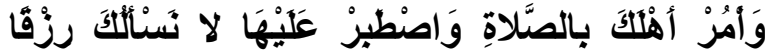

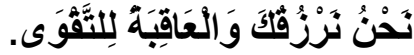

"Dan perintahkanlah kepada keluargamu mendirikan shalat dan bersabarlah] kamu dalam mengerjakannya. Kami tidak meminta rezeki kepadamu, Kamilah yang memberi rezeki kepadamu. Dan akibat (yang baik) itu adalah bagi orang yang bertakwa" (Kementerian Agama Republik Indonesia, 2014: 321).

Ayat di atas menjelaskan bahwa Allah SWT memerintahkan kepada manusia untuk mendirikan sholat dan bersabar dalam mengerjakanya. Yang dimaksud dengan bersabar dalam mengerjakanya ialah tidak terburu-buru dalam melaksanakan sholat, dan sholat tersebut dilakukan setiap waktu dan sampai akhir hayat. Hal ini sejalan dengan teori behaviorisme yang mengutamakan pengkodisian (clasiccal conditioning), pengulangan, dan penguatan, karena perintah mendirikan sholat terus berlaku sepanjang hayat, dilakukan berulangulang hingga menjadi sebuah aktifitas kebiasaan dan keharusan. Begitupun dengan belajar, belajar dalam teori ini hendaklah dilakukan secara berulangulang agar apa yang disampaikan pendidik dan apa yang diinginkan pendidik dari proses pembelajaran dapat tercapai. Selain itu diperlukan juga pengkondisian terhadap lingkungan belajar, karena lingkungan belajar dapat mempengaruhi hasil belajar peserta didik (perilaku peserta didik).

Teori belajar behaviorisme dalam relevansinya dengan pendidikan Islam dipandang baik hal ini dikarenakan teori belajar behaviorsime dapat digunakan atau dimanfaatkan untuk membantu pendidik dan peserta didik dalam proses pembelajaran, khususnya pembelajaran pendidikan Islam. Menurut teori behaviorisme dalam belajar terdapat stimulus dan respon yang memiliki unsurunsur, sebagai berikut: (1) Dorongan atau drive (2) Stimulus atau rangsangan (3) Respons (4) Penguatan atau reinforcement 
(Winataputra, 2011: 2.6). Reinforcement atau penguatan dalam teori behaviorisme dapat diaplikasikan dalam proses belajar terhadap anak-anak, akan tetapi apabila reinforcement tersebut tidak diberikan maka kebiasaan yang sudah terbentuk akan musnah (Rufaedah, 2017: 27). Dengan kata lain reinforcement tersebut harus selalu diberikan agar perilaku peserta didik yang sudah terbentuk tidak menghilang.

B.R. Hergenhahn \&Matthew H. Olson (2008: 64-65) dari Edward L. Thorndike bahwa teori belajar behaviorisme memiliki beberapa hukum diantaranya: law of readiness (hukum kesiapan), law of exercise (hukum latihan), law of effect (hukum efek), dan law of attitude (hukum sikap). Beberapa hukum tersebut memiliki hubungan atau kaitan dengan pendidikan Islam, berikut uraianya:

Pertama, law of readiness (hukum kesiapan). Belajar dalam hukum ini akan berhasil apabila seorang individu memiliki kesiapan. Oleh karena itu dalam Islam sebelum memulai suatu pembelajaran dianjurkan untuk mempunyai niat dan berdoa terlebih dahulu, dengan maksud sebagai bentuk kesiapan dari diri peserta didik sebelum memuliai proses pembelajaran.

Kedua, law of exercise (hukum latihan). Belajar dalam hukum latihan dipandang akan berhasil apabila banyak dilakukan latihan-latihan, ulangan, pengulangan dan lain-lain. Dalam Islam hukum latihanini dipandang baik dan relevan hal ini dikarenakan Islam sendiri sangat menghargai perbuatan yang dilakukan secara berulang-ulang atau terus menerus, karena jika suatu pembelajaran atau perbuatan dilakukan secara terus menerus maka secara tidak langsung akan menjadi kebiasaan dan akan berpengaruh terhadap pola tingkah laku seseorang. Berikut firman Allah SWT dalam Q.S. Al-Isra' ayat 41:

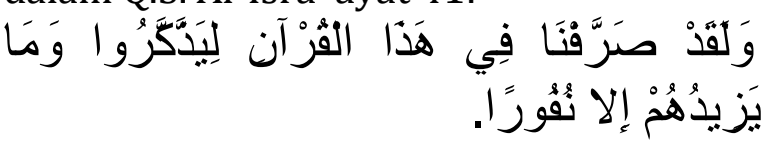

"Dan sesungguhnya dalam Al-Quran ini Kami telah ulang-ulangi (peringatanperingatan), agar mereka selalu ingat. Dan ulangan peringatan itu tidak lain hanyalah menambah mereka lari (dari kebenaran)". (Kementerian Agama Republik Indonesia, 2014: 286).

Ketiga, law of effect (hukum efek). Belajar dalam hukum efek akan dilakukan oleh seseorang dengan penuh semangat apabila seseorang tersebut mengetahui apa yang akan ia dapat setelah belajar, seperti: setelah anak belajar dengan sungguh-sungguh ia akan mendapat nilai sempurna dan jika ia mendapat nilai sempurna ia akan mendapatkan hadiah dari kedua orang tuanya. Dalam hal ini reward atau didalam Islam dikenal dengan istilah tsawab memiliki peranan yang sangat penting dalam proses pembelajaran. Artinya ketika seorang peserta didik belajar dan ia mengetahui akan mendapatkan reward setelah belajar yang ia lakukan, maka hal ini akan mendorong peserta didik untuk belajar dengan penuh antusias dan sungguhsungguh. Maka dalam hal ini reward yang diberikan selain bersifat duniawi (tswab ad-dunya) hendaklah juga bersifat ukhrawi (tsawab al-akhirah) yang akan Allah SWT dikemudian hari. Berikut firman Allah dalam Q.S. Al-Imran ayat 148:

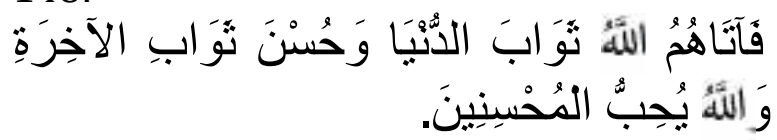

"Karena itu Allah memberikan kepada mereka pahala di dunia dan pahala yang baik di akhirat. Dan Allah menyukai orang-orang yang berbuat kebaikan." (Kementerian Agama Republik Indonesia, 2014: 68).

Keempat, law of attitude (hukum sikap). Belajar dalam hukum sikap dapat terwujud dalam bentuk perilaku setelah dilakukanya proses belajar. Dalam hal ini sikap seseorang dipengaruhi oleh apa yang ia dapat dari suatu proses pembelajaran. Belajar dalam kaitanya dengan pendidikan Islam di pandang 
sebagai proses pembentukan atau pencipataan insan kamil yang berahlak mulia, bertaqwa dan menyembah tuhan Yang Maha Esa (Pratama, 2017: 49). Ahlak mulia atau yang biasa kita sebut dengan perilaku yang baik ialah merupakan bentukan dari hasil belajar peserta didik. Oleh karena itu dalam pendidikan Islam yang menjadi landasan utamanya adalah alquran dan hadis dengan maksud untuk membentuk suatu perilaku, sikap, atau ahlak yang mulia. Berikut firman Allah dalam Q.S. Al-Hujurat ayat 11:

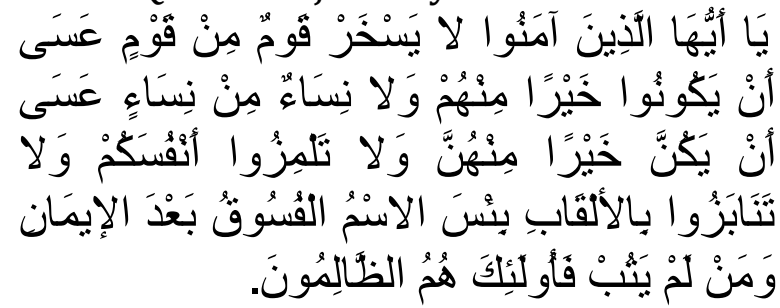

"Hai orang-orang yang beriman, janganlah sekumpulan orang laki-laki merendahkan kumpulan yang lain, boleh jadi yang ditertawakan itu lebih baik dari mereka. Dan jangan pula sekumpulan perempuan merendahkan kumpulan lainnya, boleh jadi yang direndahkan itu lebih baik. Dan janganlah suka mencela dirimu sendiri dan jangan memanggil dengan gelaran yang mengandung ejekan. Seburuk-buruk panggilan adalah (panggilan) yang buruk sesudah iman dan barangsiapa yang tidak bertobat, maka mereka itulah orang-orang yang zalim." (Kementerian Agama Republik Indonesia, 2014: 516).

Berdasarkan beberapa penjelasan diatas maka penulis dapat menganalisis bahwa relevansi teori belajar behaviorisme terhadap pendidikan Islam ialah sebagai berikut: Pertama, teori belajar behaviorisme merupakan sumbangsih pengetahuan yang dapat digunakan untuk membantu proses pembelajaran pendidikan Islam.

Kedua, teori belajar behaviorisme merupakan teori belajar yang sejalan dan berkaitan dengan ajaran agama Islam. Hal ini dapat dilihat dari stimulus dan respon yang ada pada teori behaviorisme. Dimana stimulus tersebut dapat digambarkan dalam bentuk lingkungan yang mempengaruhi individu.

Ketiga, adanya pengkondisian (clasical conditoning), pengulangan dan penguatan, dimana hal ini juga sejalan/berkaitan dengan ajaran agama Islam, karena dalam pendidikan Islam prinsip pengulangan dan penguatan ialah prinsip yang biasa digunakan dalam pembelajaran pendidikan Islam.

Keempat, pada teori behaviorisme yang dikemukakan Edward Lee Thorndike terdapat empat hukum yaitu: (1) Law of radiness (hukum kesiapan) (2) law of exercise (hukum latihan) (3) Law of effect (hukum latihan) (4) Law of attitude (hukum sikap). Menurut analisis penulis terhadap keempat hukum tersebut maka dapat disimpulkan bahwa keempat hukum tersebut ialah sejalan/berkaitan dengan proses pembelajaran pendidikan Islam, hal ini dapat dilihat dari: (1) Law of radiness (hukum kesiapan) dimana sebelum memulai pembelajaran peserta didik membaca do'a belajar (2)Law of exercise (hukum latihan) yang berupa pemberian latihan-latihan serta pengulangan-pengulangan dalam pembelajaran (3) Law of effect (hukum efek) yang berupa pemberian reward terhadap hasil yang memuaskan yang diperoleh peserta didik. (4) Law of attitude (hukum sikap) yang berupa sikap atau perilaku yang diperoleh dari hasil pembelajaran.

\section{HASIL PENELITIAN DAN PEMBAHASAN Teori Belajar Behaviorisme}

Teori belajar behaviorisme ini merupakan sebuah aliran teori yang lebih menekankan pada pembentukan tingkah laku berdasarkan stimulus dan respon yang dapat diamati (Rusuli, 2013: 39). Menurut aliran behaviorisme belajar pada hakikatnya ialah merupakan proses pembentukan asosiasi antara kesan yang ditangkap panca indera dengan kecenderungan untuk bertindak antara stimulus dan respon, sehingga dalam teori 
ini belajar dapat dipahami sebagai upaya untuk membentuk hubungan antara stimulus dan respon sebanyak-banyaknya (Sanjaya, 2008: 237).

Belajar dalam teori behaviorsime merupakan sebuah perubahan perilaku, khusunya perubahan kapasitas peserta didik untuk berperilaku yang baru sebagai hasil belajar dan bukan sebagai hasil pendewasaan semata (Sanjaya, 2008: 237). Menurut teori behaviorisme perubahan perilaku manusia sangat dipengaruhi oleh lingkungan yang akan memberikan beragam pengalaman kepada kehidupan seseorang. Lingkungan merupakan stimulus yang dapat mempengaruhi atau mengubah kapasitas untuk respons. John B. Watson percaya bahwa semua mahluk hidup menyesuaikan dirinya melalui respon teresbut. Hal ini lah yang menjadi landasan dasar dari adanya teori belajar behaviorisme (Sanjaya, 2008: 238).

Dari beberapa penjelasan di atas maka dapat dipahami bahwa teori belajar behaviorisme merupakan teori belajar yang menekankan pada aspek pembentukan tingkah laku serta perubahan tingkah laku yang didasarkan pada stimulus dan repons yang diberikan.

\section{PENUTUP}

Teori belajar behaviorisme memandang belajar sebagai proses perubahan tingkah laku sebagai akibat dari adanya interaksi antara stimulus dan respons. Edward Lee Throndike dengan teori connectionismenya menyatakan bahwa belajar merupakan proses pembentukan hubungan (connection) antara stimulus dan respons yang diberikan oleh organisme terhadap stimulus awal. Sedangkan John Broadus Watson dengan teorinya Sarbon(stimulus and response bond theory menyatakan bahwa belajar merupakan proses terjadinya refleks-refleks atau responsrespons bersyarat melalui stimulus. Dengan begitu maka belajar menurut teori behaviorisme hendaklah meliputi stimulus dan respon yang dapat membentuk perilaku seseorang sebagai akbiat dari belajar.

Berdasarkan analisis penulis terhadap relevansi teori belajar behaviorisme Edward Lee Throndike dan John Broadus Watson dengan pendidikan Islam, diperoleh hasil sebagai berikut: (1) Teori belajar behaviorisme merupakan sumbangsih pengetahuan yang dapat digunakan untuk membantu proses pembelajaran pendidikan Islam (2) Teori belajar behaviorisme sejalan dan berkaitan dengan ajaran agama Islam (3) Adanya pengkondisian, penguatan, dan pengulangan yang juga digunakan dalam pembelajaran pendidikan Islam (4) Adanya keempat hukum yang juga digunakan dalam proses pembelajaran pendidikan Islam, seperti: law of radiness (hukum kesiapan) dimana sebelum memulai pembelajaran peserta didik membaca do'a belajar, sebagai bentuk kesiapan.[]

\section{DAFTAR RUJUKAN}

Andriyani, Fera. "Teori Belajar Behavioristik dan Pandangan Islam tentang Behavioristik." Jurnal Pendidikan dan Pranata Islam, 10.2 (2015): 165-180.

Dahar, Ratna Wilis. Teori-teori Belajar dan Pembelajaran, Jakarta: Erlangga, 2011.

Djiwandono, Sri Esti Mulyani. Psikologi Pendidikan, Jakarta: Depdikbud, 1989.

Hergenhahn, B. R.\& Olson, Matthew H. Theories Of Learning: Teori Belajar, Jakarta: Kencana Media Group, 2008.

Irwan. "Teori Belajar Aliran Behavioristik Serta Implikasinya dalam Improvisasi Jazz Jurnal." Jurnal PPKN dan Hukum, 10.2 (2015): 95-117.

Kementerian Agama Republik Indonesia. Al-Qur'anul Karim dan Terjemah. Surakarta: Az-Ziyadah, 2014. 
Moelong, Lexy J. Metode Penelitian Kualitatif, Bandung: PT. Remaja Rosdakarya, 2015.

Muchith, M. Saekhan. Issu-Issu Kontemporer dalam Pendidikan Islam, Kudus: STAIN Kudus, 2009.

Muflihin, Muh Hizbul. "Aplikasi dan Implikasi Teori Behaviorisme dalam Pembelajaran (Analisis Strategis Inovasi Pembelajaran)."Khazanah Pendidikan, 1.2 (2009). 1-11.

Nahar, Novi Irwan. "Penerapan teori belajar behavioristik dalam proses pembelajaran." Nusantara: Jurnal Ilmu Pengetahuan Sosial 1.1 (2016). 64-74.

Nata, Abudin. Manajemen Pendidikan, Mengatasi Kelemahan Pendidikan Islam di Indonesia, Jakarta: Prenada Media Group, 2008.

Pratama, Yoga Anjas. Penggunaan Media Komikdalam Peningkatkan Hasil Belajar Peserta Didik di SDN 1 Sukabumi Bandar Lampung, Skripsi: FTIK UIN Raden Intan Lampung, 2017.

Rahyubi, Heri. Teori-Teori Belajar dan Aplikasi Pembelajaran Motorik: Deskripsi dan Tinjauan Kritis, Bandung: Nusa Media, 2014.

Ratnawati, Etty. "Karakteristik Teori-Teori Belajar dalam Proses Pendidikan (Perkembangan Psikologis dan Aplikasi). "Edueksos: Jurnal Pendidikan Sosial \& Ekonomi, 4.2 (2016). 1-23.

Rufaedah, Evi Aeni. "Teori Belajar Behavioristik Menurut Perspektif Islam."Jurnal Pendidikan dan Studi Islam 4.1(2017): 14-30.

Rusuli, Izzatur. "Refleksi Teori Belajar Behavioristik dalam Persepektif Islam." Jurnal Pencerahan, 8.1 (2014): 38-54.

Sanjaya, Wina. Kurikulum dan Pembelajaran: Teori dan Praktik Pengembangan Kurikulum Tingkat Satuan Pendidikan, Jakarta: Prenada Media Group, 2008.
Siregar, Eveline \& Nara, Hartini. Teori Belajar dan Pembelajaran, Bogor: Ghalia Indonesia, 2011.

Sudiyono, M. Ilmu Pendidikan Islam, Jakarta: PT. Rineka Cipta, 2009.

Suyono. dan Hariyanto. Belajar dan Pembelajaran, Bandung: PT. Remaja Rosdakarya, 2011.

Winataputra, Udin S. dkk. Teori Belajar dan Pembelajaran, Jakarta: Universitas Terbuka, 2011.

Yuningsih, Aryani. Penerapan Teori Belajar Behavioristik (Thorndike) Melalui Teknik Drill and Pratice Untuk Meningkatkan Aktivitas Belajar Siswa Pada Bidang Studi Bahasa Indonesia dalam Manteri Mengarang Siswa Kelas V SDN 023 Sedinginan Kecamata Tanah Putih, Skripsi: FITK Universitas Islam Negeri Sultan Syarif Kasim Riau Pekanbaru, 2011.

Zulhammi. "Teori Belajar Behavioristik dan Humanistik dalam Perspektif Islam." Jurnal Darul Ilmi, 3.1 (2015): 105-127. 